DOI https://doi.org/10.15407/usim.2018.02.012

UDK 004.02

VLADIMIR KALMYKOV, PhD, Senior research fellow

vl.kalmykov@gmail.com

ANTON SHARYPANOV, Research fellow,

_sha_@ukr.net

Institute of Mathematical Machines and Systems Problems of the Ukraine National Academy of

Science (IMMSP NASU), prosp. acad. Glushkova 42, Kyiv, 03187, Ukraine

\title{
SEGMENTATION OF THE EXPERIMENTAL CURVES AS THE IMPLEMENTATIONS OF UNKNOWN PIECEWISE SMOOTH FUNCTIONS
}

While processing (e.g. spline approximation) of experimental curves that supposed to be implementations of piecewise smooth functions distorted by noise, the task of determining the boundary points of the pieces arises. A suitable resolution for examining each curve is unknown. Construction of partial answers at a number of increasing resolutions is proposed. Each partial answer contains information about specific points found at a given resolution. The general answer is a subset of maximum cardinality of sequential and not conflicting partial answers. The results of experiments on segmentation of curves based on proposed method are discussed.

Keywords: experimental curves, segmentation, coarse-to-fine.

\section{Introduction}

Most information systems accumulate information in the form of various diagrams, various kinds of images, which are required to obtain the opinion of the expert, in other words, to take this or that decision. A large and constantly growing volume of data is forcing the development of tools that allow reducing the burden on the decisionmakers through automatic and/or automated processing of raw data.

The initial data or experimental curves represent the measurement results that are usually distorted by interference. It is assumed that the measured data is the representation of some unknown function $\mathrm{y}=\mathrm{f}(\mathrm{x})$, that is defined on measuring range $[a, b]$. Measurement result is a finite sequence of $I$ pairs $\left\{x_{i}, y_{i}\right\} ; i=1,2 \ldots I$. In other words, there is a tabular implementation of a given function.
Diagrams, contours of objects on images seems to be the simplest and long used method for cognitive presentation of measurements in various areas of human activity, which allow to evaluate the qualitative properties of the process despite on the interference and measurement error. The most basic feature of a diagram or contour is its shape, which reflects a function that generates a visible representation of the curve. It is the form of graphic curve that characterizes parameters of the reflected object or process. Various representations can vary in scale, in the number of measurements, and in other affine transformations. Furthermore, they may be distorted by noise. However, the main features of the form are preserved. Automatic (automated) processing of graphical representation of unknown functions implementations involves comparing their forms to determine if they describe the same or different processes or 
objects. For that purpose an analytical representation of an object should be obtained, e.g. in the form of parametrically defined splines [1, 2].

However, the methods of presentation of the experimental curves by splines suggest that obtained experimental curves represent processes or phenomena that are determined by unknown smooth functions. At the same time a large number of practical problems require processing of the experimental curves that can not be represented by smooth functions adequately. Apparently, these diagrams are the representations of the processes determined by the unknown piecewise smooth function.

It is natural to assume that the approximating function must also be piecewise smooth. The curve defined by the function $y=f(x),(a \leq x \leq b)$ is piecewise smooth if the function $y=f(x)$ has a finite number of discontinuities on $[a, b]$ and the segment $[a, b]$ can be divided by points into a finite number $N$ of partial segments, so that the function $y=f(x)$ has continuous derivatives not equal to zero simultaneously on each segment.

If splines are selected as approximating function, this function takes the form of a sequence of polynomials

$$
\begin{gathered}
y=f^{(1)}(x)\left|\left(t_{0} \leq x<t_{1}\right), f^{(2)}(x)\right|\left(t_{1} \leq x<t_{2}\right), \ldots, \\
f^{(N-1)}(x) \mid\left(t_{N-1} \leq x \leq t_{N}\right),
\end{gathered}
$$

where

$$
f(x) \mid\left(t_{n} \leq x<t_{n+1}\right)=a_{0}^{(n)} x^{k}+a_{1}^{(n)} x^{k-1}+\ldots+a_{k-1}^{(n)} x+a_{k}^{(n)} .
$$

Thus, it is necessary to consider a set of boundary points $T=\left\{t_{0}, t_{1}, \ldots, t_{N}\right\}$ and their number $N+1$ in order to segment the experimental curve (Figure 1).

The phenomenon of selecting the separate segments on a diagram is an act of visual perception by its nature. The discontinuities of the curve or its gradient are identified visually and used for making decisions. The segmentation of images (i.e. object contour selection) presumably has the same nature as diagram segmentation.

The goal of this paper is to present the new method for experimental curve segmentation based on variable resolution concept prototyped from visual system of humans and animals.

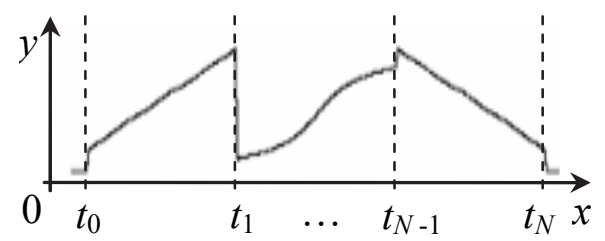

Fig. 1. Segmentation of experimental curve

In Sect. 2 we overview some existing methods of image processing to show that de facto resolution changes is widely used to reduce the computational complexity of existing image processing algorithms in order to get performance gain. However the resolution that is best suited for processing particular image is never estimated.

Since the segmentation of diagrams is an act of visual perception and the result of segmentation is a set of points that bound continuous segments of the curve we establish correspondence between changes in sizes of visual neuron receptive field and discontinuity analyses from calculus in Sect. 3.

We propose a coarse-to-fine algorithm for experimental curve segmentation and discuss the results of its work in Sect. 4, 5.

\section{Image processing methods that use resolution changes}

Usually image processing systems deal with an image distorted by noise. In the simplest case input image is convolved with (typically) Gaussian filter in order to remove unwanted details and processing algorithm is applied to blurred image. For example Canny edge detector [3] relays on that processing procedure. The result depends on $\sigma$ parameter of Gaussian filter (Figure 2). No recommendations were issued in original work on how to choose that parameter.

Other filters can also be used during signal preprocessing aiming at removing noise from the original signal. The result depends on the apperture size of the filter which is the unknown parameter.

It was shown in [4] that processing of artificially blurred images allows to solve problems that can not be addressed at all by traditional image recognition methods but nothing was said about choosing the reasonable degree of that blur. 


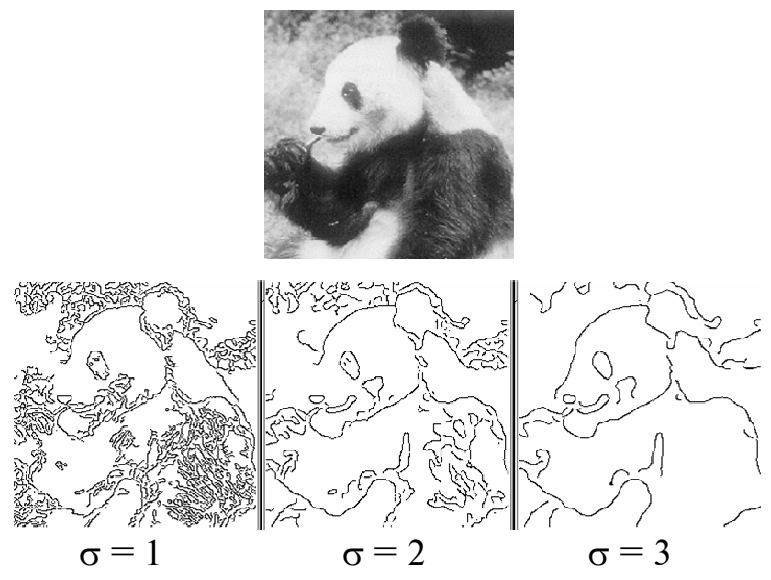

Fig. 2. Application of Canny edge detector with different values of $\sigma$ to an image

In some fields of science it is not possible to get sharp image at one shot. In biological imaging with conventional light microscopy a problem of limited depth of focus exists. If the specimen is thicker than attainable focal depth portions of the object surface outside the focal plane will be defocused. To overcome this, multiple shots of specimen are taken with different focal depth along optical axis resulting in series of images where the certain parts of specimen appear in and out of focus. After that a procedure of reconstruction from image set involving wavelets follows in order to obtain an image that is sharp everywhere [5].

However, blurring of an image may be considered as decreasing of physical resolution. At the same time decreasing of physical resolution is widely used to reduce the computational complexity of existing image processing algorithms in order to get performance gain.

In [6] proposed a multi-resolution part based model and a corresponding coarse-to-fine inference algorithm. It is based on the observation that matching of each part of the image is the most expensive computational operation in comparison to detection of significant parts and computation of their optimal configuration, so the minimization of number of part-to-image comparisons implies detection acceleration. Starting from matching the lowest resolution part the method selects only the best placement in each image neighbor- hood. These locally optimal placements are then propagated recursively to the parts at higher resolution. By recursive elimination of unlikely part placements from the search space, the set of possible locations is narrowed so that the computation of only few part-to-image comparisons is performed. This method gives a ten-fold speed-up over the standard dynamic programming approach.

The task of establishing the correspondence between pixels in two images (finding a markup) with human faces, addressed in [7], is effectively solved by building "cascades" of markups. The resolution is decreased two times in both initial images per cascade and new markup for them is built. After that the starting approximation for initial markup is defined based on the new markup and the field of motion is searched but with less quantity of markings. The algorithm that solve the task utilizing one "cascade" runs eight times faster while preserving accuracy in finding the field of motion for two images.

As we can see, several fixed decreased resolutions relative to resolution of original image are taken and transition rules are introduced but the best resolution for processing particular image or its part is never estimated.

\section{Necessary additional mathematics and neurophysiology information}

We will conduct our research based on the classical definition of the continuity of functions and new findings in the field of neurophysiology of vision.

The definition of function continuity in $\varepsilon-\delta$ form states that if for every $\varepsilon>0$ there exists a $\delta>0$ such that for all values of variable $x$ from $\delta$ neighborhood of point $\mathrm{c}$ the function values $f(x)$ belong to $\varepsilon$-neighborhood of $f(c)$ (Figure 3).

This definition is used successfully for function analysis but it could not be used in analysis of experimental curves. Experimental curves are the representations of respective unknown functions presented as sequences of measurements. A sequence of measurements is a set of points in some 
discrete space. We note only that for checking the continuity condition of $f(x)$ in a given point $\mathrm{c}$ the sequence of function values considers. Starting from a specific value $\left|x_{1}-c\right|$ the neighborhood of point c reduces $\left(\left|x_{1}-c\right|>\left|x_{2}-c\right|,\left|x_{2}-c\right|>\left|x_{3}-c\right|\right.$, ...) tending to $0 . f(x)$ considers continuous in $\mathrm{c}$ if the neighborhood of $f(c)$ reduces to 0 at the same time $\quad\left(\left|f\left(x_{1}\right)-f(c)\right|>\left|f\left(x_{2}\right)-f(c)\right|, \quad\left|f\left(x_{2}\right)-f(c)\right|>\right.$ $\left.>\left|f\left(x_{3}\right)-f(c)\right|, \ldots\right)$. So, changing neighborhood of $\mathrm{c}$ is used for analysis of function continuity in a given point.

While studying human vision and processes which take place in visual system neurophysiologists discovered that visual neurons process signals from a set of receptors that form receptive field of a neuron. The simplest receptive fields are circle in shape and discrete by their nature. Receptive fields of neighboring neurons overlap [8]. Later it was discovered that the excitatory zone of the receptive field doesn't stay constant during a visual act (approx. 150ms). It decreases from maximum to $1-2$ receptors wide (Figure 4). After awhile this phenomenon was carefully investigated in [10]. It was also shown in [10] that the number of neurons being activated decrease during stimulation of visual act. Eccentric stimulus spot presented outside minimum field center but inside maximum field center gave a fast initial response that disappeared as center shrank toward minimum.

Thus it is possible to assume that visual neuron could be matched to a point in some discrete twodimensional space and the excitatory zone of the neuron could be matched to discrete representation of point neighborhood. Then changes in receptive field excitatory zone could be matched to changes in point neighborhood. During one visual act image processing of the object in the field of view proceeds in visual system with different resolution changing from minimal (coarse, blurred) to maximal (sharp image). Because of the fact that we do not notice the process of image segmentation of the object in the field of view, it could be supposed that image preprocessing in visual system happens on subconscious level thanks to changes in size of visual neurons receptive field excitatory zone as well. Mentioned above phenomena being observed in visual system of living beings could be used to pro-

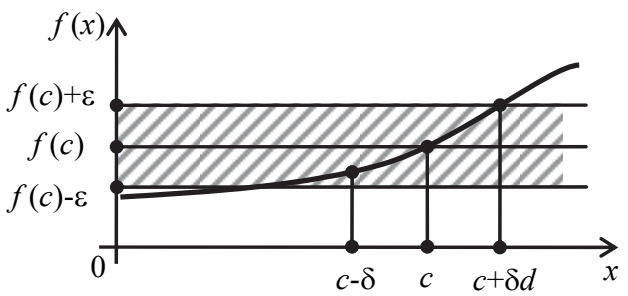

Fig. 3. Function continuity in $\varepsilon-\delta$ form

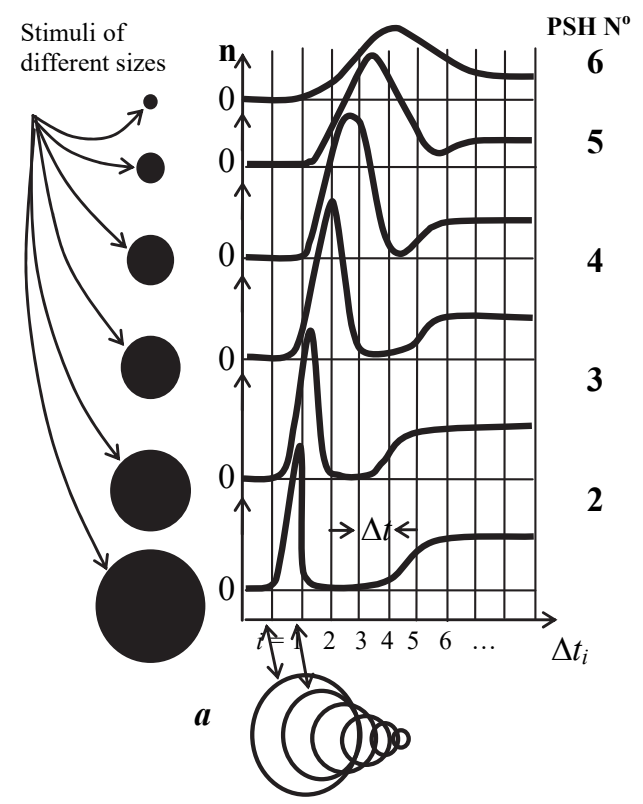

Fig. 4 [9]. Post stimulus histograms of neuron responses on stimuli of 6 different sizes $n$ axes represents the number of spikes in corresponding time slice $\Delta$ ti. Maximum number of spikes corresponds to interval where the size of stimulus meets the excitatory zone size. $a-$ decreasing of receptive field's excitatory zone area during visual act.

totype a new method of signal processing based on variable resolution concept.

\section{Proposed algorithm}

Statement of the problem: there exists an unknown function $y=f(x)$ with domain bounded to $[a, b]$. The image of this function is observed on $[a, b]$. The resolution needed for analyzing the image of this function is unknown. Under the assumption that the given image of a function represents an unknown piecewise smooth function, the boundaries of partial segments $a=t_{0}<t_{1}<\ldots<t_{N}=b$ and their number $N+1$ should be found. 


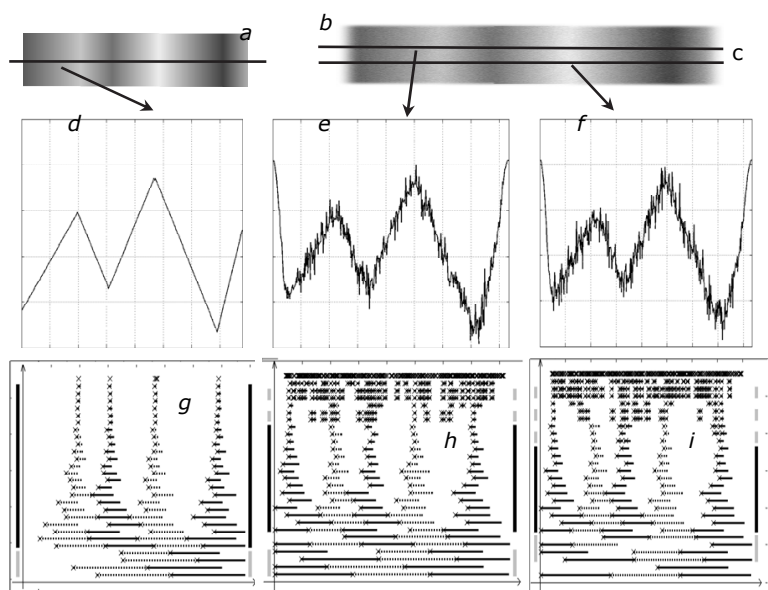

Fig. 5. Generation of segmentation answers for brightness diagrams of image lines 1 . Lines in $a-$ ideal image $b, c-$ image distorted by noise and their corresponding diagrams of brightness $d, e, f$. 2. $g, h, i-$ the results of segmentation for each diagram

Analytical solution of the segmentation problem stated above should be considered as finding the points of discontinuity for unknown piecewise smooth function. The following discontinuities are of interest: jump discontinuities, when the $\varepsilon$-neighborhood of the function is empty in a given point and removable discontinuities when the first order derivative of function does not exist in the given point (jump discontinuity of function gradient). However only the image of unknown piecewise smooth function is observed so we are allowed to consider only the discrete analog of discontinuities in the form of irregular points on experimental curve.

Preliminary stage consists of presenting the experimental data as I "reference-value" pairs $\left\{i, x_{i}\right\}$; $i=1,2 \ldots I$, that corresponds to maximum resolution. Acquisition of coarse resolution signal is performed (as well as in visual system) using a source signal with maximum resolution. The following initial conditions are set in algorithm that implements this method:

1. Maximum neighborhood size of an arbitrary reference $\mathrm{i}$ for the coarsest resolution is taken as $s_{0} \sim I / 10$.

2. List of $M$ resolutions is used with neighborhood sizes of $s_{0}, s_{1}, s_{2}, \ldots, s_{m}, \ldots, s_{M} ; s_{m+1}=k \cdot s_{m}$. In this case the value of $k$ is 0.67 . The $M$-th list item corresponds to source sequence with maximum resolution. $M$ can be calculated based on $s_{0}$ and $k$.

3. The total number of values in the sequence corresponding to resolution $\mathrm{sm}$ is $N_{m}=3 \times$ $\times\left(I / s_{m}+4\right)$ considering the mutual intersection of adjacent samples neighborhoods and additional points at the beginning and at the end of experimental curve in order to deal with border effects.

4. $g\left(s_{m}\right)$ is the curve for resolution $s_{m}$. Its $n$-th value $g_{n}\left(s_{m}\right)$ is calculated as median of values $\overline{x_{i}, x_{s}}$ for the sequence of references $i, i+1, \ldots$ $\ldots, i+s_{m}$ in experimental curve.

5. The points of $g\left(s_{m}\right)$ being calculated with non-overlapping neighborhoods are considered. Irregular points $r_{n}\left(t_{m}\right),\left(t_{m}=1,2, \ldots, T_{m}\right)$ are fixed based on analysis of curves $g\left(s_{m}\right): \mid g_{n}\left(s_{m}\right)-g_{n}-$ $-3\left(s_{m}\right) \mid>d$ and $g^{\prime}\left(s_{m}\right): g_{n}^{\prime}\left(s_{m}\right)=\left|g_{n}\left(s_{m}\right)-g_{n}-3\left(s_{m}\right)\right|$; $\left|g_{n}^{\prime}\left(s_{m}\right)-g_{n}^{\prime}-3\left(s_{m}\right)\right|>d$. Here $d$ is some predefined threshold.

6. Application of rules from item 5 to curves $g(s)$ and $g^{\prime}(s)$ for all $M$ resolutions results in a list of irregular points sequences $r(T)$. Each sequence includes all irregular points $r\left(T_{m}\right)$ of curves $g\left(s_{m}\right)$ and $g^{\prime}\left(s_{m}\right)$ for a given resolution $s_{m}$.

7. Irregular point $r_{n}\left(t_{m}+1\right)$ from sequence $m+1$ corresponds to irregular point $r_{n}\left(t_{m}\right)$ from sequence $m$ respectively if $r_{n}\left(t_{m}\right) \leq r_{n}\left(t_{m}+1\right) \leq r_{n}\left(t_{m}\right)+$ $+s_{m}$ is true.

8. Sequences $m$ and $m+1$ are grouped together in a sublist if they have equal number of irregular points Tm and the correspondence condition for each pair of respective irregular points is fulfilled. If sequence $m$ already belongs to another sublist then sequence $m+1$ is added to that same sublist.

The result of segmentation is considered as sequence of irregular points with the largest resolution number $\mathrm{m}$ being taken from the longest sublist.

\section{Discussion}

Proposed algorithm was experimentally checked in MATLAB development environment.

The diagrams of line brightness in grayscale images were selected as objects of concern (Figure $5 a-f)$. Figure $5 g-i$ shows the application of proposed algorithm to original diagram where the 
resolution (apperture size) changes from coarse (large values) to fine (small values). $X$-axis of Figure $5 g-i$ contains references of original signal (Figure $5 d-f$ respectively). $Y$-axis of Figure $5 g-i$ contains resolution numbers in a list of resolutions so each horizontal line on them represents the sequence of irregular points for a given resolution. Sublists of partial answers are marked by vertical gray dashed lines on the sides of each diagram and the longest sublists are marked in black.

In contrast to other known methods of segmentation the proposed algorithm doesn't use any a priori information about noise level etc. for the diagram been processed.

The information found on maximum resolution of the answer from segmentation is used to determine position of irregular points on subsequent resolutions of the curve up to maximum resolution.

\section{Conclusion}

For the first time it was proposed and experimentally verified curve segmentation method that used variable resolution (coarse-to-fine) in the decision-making process. Similar principle was found and studied in the visual system of animals. Using the "coarse-to-fine" principle it is possible to successfully execute segmentation of experimental curves distorted by noise, which are the implementations of piecewise smooth functions.

The resolution of signal was considered as a hidden parameter. It was shown that proposed algorithm was capable of obtaining results of segmentation based on artificially acquired information about image resolution. No additional a priori information about noise level was used while processing diagrams distorted by noise.

These solutions will be used in the development of new methods for processing halftone images.

\section{REFERENCES}

1. Vishnevskey Vitaliy, Kalmykov Vladimir, Romanenko Tatyana. Approximation of experimental data by Bezier curves // Int. J. "Information theories \& applications", Sofia, 2008, v. 15, N 3, P. 235.

2. Romanenko Tatyana, Vishnevskey Vitaliy, Kalmykov Vladimir. Analytical Representation of Graphs by Means of Parametrically Defined Splines // Proceedings of the international conference on applications of information and communication technology and statistics in economy and education ICAICTSEE, 2013 Dec. 6-7th, 2013, UNVE, Sofia, Bulgaria, P. 536-542.

3. Canny J.F. "A computational approach to edge detection," IEEE Trans. Pattern Anal. Machine Intell., vol. PAMI-8, 1986, N 6, P. 679-698.

4. Sharypanov Anton, Antoniouk Alexandra, Kalmykov Vladimir. Joint study of visual perception mechanism and computer vision systems that use coarse-to-fine approach for data processing, Int. J. "Information content \& processing", Sofia, 2014., v. 1, N 3, P. 287-300.

5. Forster B., Van De Ville D., Berent J., Sage D., Unser M. "Complex Wavelets for Extended Depth-of-Field: A New Method for the Fusion of Multichannel Microscopy Images," Microsc. Res. Tech., Sept. 2004, 65(1-2), P. 33-42.

6. Pedersoli M., Vedaldi A., Gonzáalez J. A Coarse-to-fine approach for fast deformable object detection. In CVPR, june 2011

7. Tyshchenko M.A. 3D reconstruction of human face in person identification problems. $\mathrm{PhD}$ thesis. International Research and Training Center for Information Technologies and Systems, Kyiv, 2012

8. David H. Hubel. Eye, brain, and vision New York : Scientific American Library : Distributed by W.H. Freeman, 1988, 240 p. : ill.

9. Podvigin N.F. Dinamicheskie svoystva neyronnyh struktur zritel'noi sistemy. Leningrad: Nauka, 1979. 158 p.ill.

10. Ruksenas O., Bulatov A., Heggelund P. Dynamics of Spatial Resolution of Single Units in the Lateral Geniculate Nucleus of Cat During Brief Visual Stimulation. J Neurophysiol 97, 2007, P. 1445-1456.

Received 27.03.2018

В.Г. Калмиков, канд. техн. наук, старш. наук. співроб., vl.kalmykov@gmail.com

А.В. Шарипанов, наук. співроб.,_sha_@ukr.net

Інститут проблем математичних машин і систем НАН України, просп. акад. Глушкова 42, 03187, Киев, Украина

\section{СЕГМЕНТАЦІЯ ЕКСПЕРИМЕНТАЛЬНИХ КРИВИХ ЯК РЕАЛІЗАЦІЯ КУСКОВО-ГЛАДКИХ ФУНКЦІЙ}

Вступ. Велика кількість інформаційних систем накопичує інформацію у формі різноманітних графіків, за якими має дати висновок експерт. У таких системах вхідні дані або експериментальні криві являють собою результати 
вимірів, які зазвичай спотворені завадами. Для подальшої роботи з експериментальними кривими, наприклад для їх порівняння, необхідно отримати аналітичний опис кривої, тобто вказати невідому функцію, якою вона може бути апроксимована. Більшість практичних задач породжує експериментальні криві, що можуть бути адекватно апроксимовані лише кусково-гладкими функціями. У такому випадку експериментальна крива підлягає сегментації для визначення граничних точок сегментів, у межах яких вона може бути апроксимована гладкою функцією. Людина безпомилково і майже миттєво сегментує спотворені завадами графіки завдяки механізму зміни роздільної здатності у зоровому сприйнятті. Тому актуальною задачею є створення методу сегментації експериментальних кривих з використанням поняття змінної роздільної здатності.

Мета статті - подати новий метод сегментації спотворених завадами експериментальних кривих, що базується на понятті змінної роздільної здатності.

Методи: робота спирається на класичну теорію неперервності функцій з математичного аналізу та на новітні досягнення у нейрофізіології зору людини.

Результат. Уперше запропоновано та експериментально перевірено метод сегментації експериментальних кривих, у якому використовується поняття змінної роздільної здатності для прийняття рішення. Показано, що розроблений на базі нового методу алгоритм дозволяє проводити сегментацію з використанням штучно отриманої інформації стосовно роздільної здатності експериментальної кривої. При обробленні спотворених завадами експериментальних кривих апріорна інформація стосовно параметрів завад не використовувалась.

Висновок. Застосування змінної роздільної здатності дозволяє успішно сегментувати спотворені завадами експериментальні криві, що є реалізацією невідомих кусково-гладких функцій. При цьому роздільна здатність сигналу розглядається як прихований параметр.

Ключові слова: експериментальні криві, сегментація, змінна роздільна здатність.

В.Г. Калмыков, канд. техн. наук, старш. науч. сотруд., vl.kalmykov@gmail.com

A.В. Шарыпанов, науч. сотруд.,_sha_@ukr.net

Институт проблем математических машин и систем НАН Украины, просп. акад. Глушкова 42, 03187, Киев, Украина

\section{СЕГМЕНТАЦИЯ ЭКСПЕРИМЕНТАЛЬНЫХ КРИВЫХ КАК РЕАЛИЗАЦИЯ КУСОЧНО-ГЛАДКИХ ФУНКЦИЙ}

Введение. Многие информационные системы накапливают информацию в виде различных графиков, нуждающихся в заключении эксперта. В таких системах входные данные или экспериментальные кривые представляют собой результаты измерений, обычно искаженные помехами. Для дальнейшей работы с экспериментальными кривыми, например для их сравнения, необходимо получить аналитическое описание кривой, т.е. указать неизвестную функцию, которой она может быть аппроксимирована. Большинство практических задач порождает экспериментальные кривые, которые могут быть адекватно аппроксимированы только кусочно-гладкими функциями. В таком случае экспериментальная кривая подлежит сегментации для определения граничных точек сегментов, в рамках которых она может быть аппроксимирована гладкой функцией. Человек безошибочно и почти мгновенно сегментирует искаженные помехами графики благодаря механизму изменения разрешения в зрительном восприятии. Поэтому актуальна задача создания метода сегментации экспериментальных кривых с использованием понятия переменной разрешения.

Цель статьи - подать новый метод сегментации искаженных помехами экспериментальных кривых, основанный на понятии переменной разрешающей способности.

Методы: работа опирается на классическую теорию непрерывности функций по математическому анализу и на новейшие достижения в нейрофизиологии зрения человека.

Результат: впервые предложен и экспериментально проверен метод сегментации экспериментальных кривих с использованием понятия переменной разрешающей способности для принятия решения. Показано, что разработанный на базе нового метода алгоритм, позволяет проводить сегментацию с использованием искусственно полученной информации о разрешающей способности экспериментальной кривой. При обработке искаженных помехами экспериментальных кривых априорная информация о параметрах помех не используется.

Вывод: применение переменной разрешающей способности позволяет успешно сегментировать искаженные помехами экспериментальные кривые, которые служат реализацией неизвестных кусочно-гладких функций. При этом разрешение сигнала рассматривается как скрытый параметр.

Ключевые слова: экспериментальные кривые, сегментация, переменная разрешающая способность. 